\title{
Effect of aqueous ginger (Zingiber officinale) extract on sperm quality and haematology in lead acetate-treated male albino rats
}

\author{
Rita I Odo, Edmund C Mbegbu*, Lawrence N Anyanwu \\ Department of Veterinary Physiology and Pharmacology, University of Nigeria, Nsukka, Nigeria \\ *For correspondence: Email: edmund.mbegbu@unn.edu.ng; Tel: +234-8071294648 \\ Sent for review: 13 December 2019 \\ Revised accepted: 16 June 2020
}

\begin{abstract}
Purpose: To evaluate the ameliorative effects of aqueous ginger extract on sperm quality and haematology in lead acetate-treated male albino rats.

Methods: Twenty-four male albino rats used for this study were randomly assigned to four groups $(n=$ 6). Group 1 was the normal control. Lead acetate $(4 \mathrm{mg} / \mathrm{kg})$ was given to group 2 for 6 weeks. Lead acetate $(4 \mathrm{mg} / \mathrm{kg})$ and ginger $(300 \mathrm{mg} / \mathrm{kg})$ were given to group 4 simultaneously for 6 weeks, while group 4 was given lead acetate $(4 \mathrm{mg} / \mathrm{kg}$ ) for 6 weeks, and then, ginger (300 mg/kg) for another 6 weeks. Haematological parameters, including packed cell volume (PCV), white blood cell (WBC) and red blood cell $(R B C)$ counts, hemoglobin $(\mathrm{Hb})$ concentration, and differential leukocyte count were evaluated in blood obtained from the retrobulbal plexus of the rats.

Results: Sperm motility and viability were markedly lower $(p<0.05)$ in group 2 , in comparison to groups 1 and 3 , while sperm motility and viability in group 3 were similar, but differed from group $1(p<0.05)$. The sperm motility and sperm viability of groups 4 and 2 were comparable. Haematological profile showed a marked reduction in the RBC of rats in group 2, when compared to those in groups 1 and 3. The WBC of group 2 was significantly higher than those of groups 1,3 and $4(p<0.05)$.

Conclusion: The results indicate that aqueous ginger extract has the potential to protect sperm quality and haematology in lead acetate treated male rats.
\end{abstract}

Keywords: Ginger, Lead acetate, Sperm quality, Haematology

\begin{abstract}
This is an Open Access article that uses a fund-ing model which does not charge readers or their institutions for access and distributed under the terms of the Creative Commons Attribution License (http://creativecommons.org/licenses/by/4.0) and the Budapest Open Access Initiative (http://www.budapestopenaccessinitiative.org/read), which permit unrestricted use, distribution, and reproduction in any medium, provided the original work is properly credited.

Tropical Journal of Pharmaceutical Research is indexed by Science Citation Index (SciSearch), Scopus, International Pharmaceutical Abstract, Chemical Abstracts, Embase, Index Copernicus, EBSCO, African Index Medicus, JournalSeek, Journal Citation Reports/Science Edition, Directory of Open Access Journals (DOAJ), African Journal Online, Bioline International, Open-J-Gate and Pharmacy Abstracts
\end{abstract}

\section{INTRODUCTION}

Lead $(\mathrm{Pb})$ is a pollutant, that is abundant in the environment, and it is known to be harmful, and poisonous [1]. Pollution of the environment with lead has resulted to toxicities in the kidney, liver, nerves, blood, testis and ovary in man and animals [2]. Prolonged environmental pollution with lead, results to its accumulation, in the organs mentioned above, hence, causing many metabolic and histological changes in them $[3,4]$.

Research has shown that lead toxicity causes severe damage to the reproductive system, interfering with spermatogenesis, hence, decreases sperm production and quality $[5,6]$. The mechanism by which lead toxicity causes testicular damage to exposed males is by 
induction of oxidative stress, and inhibition of the body's defence to oxidants. [7]. Ginger (Zingiber officinale) is a spicy, and a medicinal plant. Its folkoric use in the treatment of inflammation of the joints, cold symptoms, sore throats, pyrexia, cramps and constipation has been reported [8]. It has also been reported to be an antioxidant, with cyto-protective effects, used in the treatment of microbial infections, inflammatory conditions and emesis [9]. Zingiber officinale contains zingerone, gingerdiol, zingibrene, gingerols and shogaols, and these constituents are antioxidants [10].

Ginger has been reported to have a preventive role on ischemia/reperfusion (I/R) injury in the rat's kidney [11]. It has also been shown to have inhibitory effect on cisplatin-induced nephrotoxicity in rats [11]. Hence, the objective of this study was to evaluate the ameliorative effects of aqueous ginger extract on the quality of epididymal sperm and haematology in lead acetate treated male albino rats.

\section{EXPERIMENTAL}

\section{Materials}

The lead $(\mathrm{Pb})$ acetate (El-Gomhoria company, Egypt) used was bought from Joe Chem Ventures Ltd, University of Nigeria, Nsukka, Enugu State. Ginger rhizome was purchased from Ogige Market in Nsukka, Nigeria in March, 2018. It was authenticated as Zingiber officinale by $\mathrm{Mr}, \mathrm{AO}$ Ozioko, a taxonomist of the Bioresources Development and Conservation Programme, Aku Road, Nsukka, Enugu State, Nigeria. A voucher specimen was kept for future reference in INTERCEDD (International Center for Ethnomedicine and Drug Development) herbarium (no. INTERCEDD/1788).

\section{Extraction of ginger (Zingiber officinale) extract}

Ceramic mortar and pestle were used to crush the ginger rhizome, and Whatman no. 1 filter paper was used for filtration. Hot air oven was used to concentrate the filtrate at $37^{\circ} \mathrm{C}$, and the filtrate was then, kept at $4^{\circ} \mathrm{C}$ during its use.

\section{Animals}

Twenty-four male albino rats (Rattus norvegicus) weighing between 180 to $200 \mathrm{~g}$ (12 weeks of age) were used in this study. The animals were sourced from the Department of Veterinary Anatomy, University of Nigeria, Nsukka and housed in clean cages at room temperature at the laboratory animal unit of Department of
Veterinary Physiology and Pharmacology, Faculty of Veterinary Medicine, University of Nigeria, Nsukka. They were acclimatized for two (2) weeks, before the experiment started, during which they were fed ad libitum with feed and water.

\section{Ethical approval}

Handling of the rats was in accordance with principles of laboratory animal care, and all the protocols and procedures were approved by the Ethical Committee of Faculty of Veterinary Medicine, University of Nigeria, Nsukka (approval ref no. 20170526). The handling is in accordance with Directive 1997/73/WE on the use of animals for experiment [12].

\section{Study design}

Twenty-four mature male strain randomly assigned to four (4) groups of six rats each were used for the study. In group 1, (normal control) distilled water was given as placebo. Rats in group 2 were treated daily with lead acetate alone at $4 \mathrm{mg} / \mathrm{kg}$ per OS [6] from day one for six weeks. Rats in group 3 were treated daily with lead acetate at $4 \mathrm{mg} / \mathrm{kg}$ and ginger extract at 300 $\mathrm{mg} / \mathrm{kg}$ orally [11] from day one for six weeks, while those in group 4 were treated for six weeks with $4 \mathrm{mg} / \mathrm{kg}$ of lead via the oral route, and then treated for more 6 weeks with $300 \mathrm{mg} / \mathrm{kg}$ of ginger extract via the same route.

\section{Measurement of testicular weight}

After 30 days of treatment, rats from each group were sacrificed using chloroform. The testes from each rat were carefully removed, free of, extraneous tissues, and the testes were measured using a weighing balance [13].

\section{Evaluation of motile sperms}

Wet mount of sperm from the cauda epididymis was made on a prewarmed slide, and a light microscope was used to view the proportion of spermatozoa, moving progressively in one direction on a slide per field [14]. Spermatozoa moving in one direction were counted, while those showing circular, pendulous or backward movements were not counted.

\section{Assessment of sperm viability}

Eosin-nigrosin stain was mixed with sperm sample on a prewarmed slide [15]. Sperm-stain smear was made, and air dried. Live (white) and dead (pink/red) spermatozoa were counted 
differently, under a microscope, and estimated in percentage [14].

\section{Evaluation of haematological parameters}

On the $30^{\text {th }}$ day of study, non-heparinized capillary tubes were inserted into the retrobulbal plexus of the rats, and blood samples were collected into EDTA sample bottles.

\section{Measurement of packed cell volume (PCV)}

This was determined with the hematocrit method [16]. Values are expressed in percentage.

Assessment of white blood cell (WBC) and red blood cell (RBC) counts

Improved Neubauer chamber was used for counting the cells [16]. Values were expressed as number of counts $\times 10^{6} / \mu$ Lof blood.

\section{Determination of hemoglobin concentration}

This was done using cyanomethaemoglobin method [16] and values recorded in $\mathrm{g} / \mathrm{dl}$

\section{Differential leukocyte count}

Lieshmann Technique [16] was used. Every leucocyte type was evaluated as a percentage of the total count, and changed to the absolute value per microlitre of blood.

\section{Statistical analysis}

Data obtained from the study were analysed using one-way analysis of variance (ANOVA). Duncan Multiple Range Test was used to separate the variant means. Marked difference was accepted at $p<0.05$.

\section{RESULTS}

\section{Testicular weight}

The testicular weights among the groups are comparable $(p>0.05)$ (Table 1).

\section{Sperm motility and sperm viability}

Sperm motility and viability of group 2 were markedly lower in comparison to groups 1 and 3 (Table 1). Sperm motility and viability in groups 3 and 1 are similar, and both are also comparable in groups 2 and 4 ( $p>0.05)$.

\section{Haematological profile}

There were significant decreases in $\mathrm{PCV}$ and $\mathrm{Hb}$ in group 2, in comparison to groups 1, 3 and 4 (Table 2). The RBC of group 2 was markedly lower in comparison to groups 1 and 3 . The WBC, was significantly higher in group 2 animals, when compared to groups 1,3 and 4 (Table 3). There was also a significant increase in the number of lymphocytes of animals in groups 2 and 4, when compared to groups 1 and 3 but all the values fell within the normal range reported for this specie. The neutrophils in groups 2 and 4 were markedly higher, when compared to groups 1 and 3 , however, all the values are normal for the specie.

\section{DISCUSSION}

The similarity in testicular weight of lead acetate treated group and other groups was however, not in line with the study that reported atrophy of the testes of rats treated with lead acetate [17]. The significant decrease in sperm motility and viability observed in group 2 (lead acetate only) animals, when compared to animals in groups 1 (normal control) and 3 (lead acetate + ginger) may be due to reactive oxygen species attack caused by lead $[18,19]$. Spermatozoa are destroyed by oxidative stress. The oxidants damage the structure of lipid matrix in the membranes of sperm cells, and this affects the quality of sperm adversely [20].

The similarity in sperm motility and viability of animals in group 3 (lead + ginger), when compared to group 1 (normal control), may be due to antioxidant properties of ginger [21-23]. Vitamin $\mathrm{C}$, an antioxidant is one of the constituents of ginger [24].

Table 1: Testicular weight, and sperm motility and viability of rats

\begin{tabular}{lcccc}
\hline Parameter & \multicolumn{3}{c}{ Group } \\
\cline { 2 - 5 } & $\begin{array}{c}\mathbf{1} \\
\text { (Normal } \\
\text { control) }\end{array}$ & $\begin{array}{c}\mathbf{2} \\
\text { (LA only) }\end{array}$ & $\begin{array}{c}\mathbf{3} \\
\text { (LA and ginger } \\
\text { SML) }\end{array}$ & $\begin{array}{c}\mathbf{4} \\
\text { (LA 6 weeks, then } \\
\text { ginger 6 weeks) }\end{array}$ \\
\hline Testicular weight (g) & $1.10 \pm 0.00$ & $0.90 \pm 0.16$ & $0.90 \pm 0.10$ & $1.07 \pm 0.03$ \\
Sperm motility (\%) & $76.68 \pm 8.82^{\mathrm{a}}$ & $30.00 \pm 5.77^{\mathrm{b}}$ & $73.33 \pm 3.33^{\mathrm{a}}$ & $40.00 \pm 5.77^{\mathrm{b}}$ \\
Sperm viability (\%) & $76.67 \pm 8.82^{\mathrm{a}}$ & $40.00 \pm 5.77^{\mathrm{b}}$ & $66.67 \pm 3.33^{\mathrm{a}}$ & $46.67 \pm 3.33^{\mathrm{b}}$ \\
\hline
\end{tabular}

Key: $a$ and $b$ are different superscripts used to show statistical differences between the mean $(p<0.05)$. LA= Lead acetate, $\mathrm{SML}=$ simultaneously 
Table 2: Packed cell volume, haemoglobin concentration and red blood cell count of rats

\begin{tabular}{|c|c|c|c|c|}
\hline \multirow[t]{2}{*}{ Parameter } & \multicolumn{4}{|c|}{ Group } \\
\hline & $\begin{array}{c}1 \\
\text { (Normal control) }\end{array}$ & $\begin{array}{c}2 \\
\text { (LA only) }\end{array}$ & $\begin{array}{c}3 \\
\text { (LA and ginger } \\
\text { SML) }\end{array}$ & $\begin{array}{c}4 \\
\text { (LA } 6 \text { weeks, then } \\
\text { ginger } 6 \text { weeks) }\end{array}$ \\
\hline $\begin{array}{l}\text { Packed cell volume } \\
(\%)\end{array}$ & $49.67 \pm 2.03^{a}$ & $41.67 \pm 0.67^{b}$ & $47.33 \pm 1.45^{a}$ & $46.33 \pm 0.88^{a}$ \\
\hline $\begin{array}{l}\text { Haemoglobin conc. } \\
(\mathrm{g} / \mathrm{dL})\end{array}$ & $10.70 \pm 0.31^{a}$ & $7.27 \pm 0.88^{b}$ & $9.10 \pm 0.23^{c}$ & $8.43 \pm 0.26^{c}$ \\
\hline $\begin{array}{l}\text { Red blood cell count } \\
\left(10^{6} / \mu \mathrm{l}\right)\end{array}$ & $28.17 \pm 1.09^{a}$ & $24.00 \pm 0.58^{b}$ & $26.00 \pm 0.58^{a c}$ & $24.33 \pm 0.33^{b c}$ \\
\hline
\end{tabular}

Table 3: Total white blood cell and differential leucocyte counts of rats

\begin{tabular}{|c|c|c|c|c|}
\hline \multirow[t]{2}{*}{ Parameter } & \multicolumn{4}{|c|}{ Group } \\
\hline & $\begin{array}{c}1 \\
\text { (Normal control) }\end{array}$ & $\begin{array}{c}2 \\
\text { (LA only) }\end{array}$ & $\begin{array}{c}3 \\
\text { (LA and ginger } \\
\text { SML) }\end{array}$ & $\begin{array}{c}4 \\
\text { (LA } 6 \text { weeks, then } \\
\text { ginger } 6 \text { weeks) }\end{array}$ \\
\hline Total WBC & $70.00 \pm 1.15^{a}$ & $82.00 \pm 2.00^{b}$ & $68.66 \pm 0.67^{a}$ & $72.00 \pm 1.15^{a}$ \\
\hline Neutrophils & $40.67 \pm 0.67^{a}$ & $30.67 \pm 0.67^{b}$ & $46.00 \pm 1.15^{\mathrm{c}}$ & $30.00 \pm 0.00^{b}$ \\
\hline Lymphocytes & $58.00 \pm 1.54^{a}$ & $68.00 \pm 1.15^{b}$ & $52.00 \pm 1.15^{c}$ & $68.00 \pm 1.15^{b}$ \\
\hline Monocytes & $2.00 \pm 0.00$ & $2.00 \pm 0.00$ & $2.00 \pm 0.00$ & $2.00 \pm 0.00$ \\
\hline Eosinophils & $2.00 \pm 0.00$ & $2.00 \pm 0.00$ & $2.00 \pm 0.00$ & $2.00 \pm 0.00$ \\
\hline
\end{tabular}

The fact that the sperm motility and viability of rats in group 4 (lead acetate 6 weeks, then ginger 6 weeks) are comparable to group 2 (lead acetate only), may be because the toxic effect of lead had occurred before commencement of treatment with ginger. This suggests that it is better to prevent lead toxicity with consumption of ginger than allowing the toxicity to occur before treatment with ginger.

The significant decreases in PCV and $\mathrm{Hb}$ concentration of group 2 (lead acetate only) when compared to groups 1 (control), 3 (lead acetate + ginger) and 4 (lead acetate 6 weeks and then ginger 6 weeks) as well as the significant decrease in RBC of group 2 , when compared to those in groups 1 and 3 are in line with previous studies [25]. Lead affects RBCs adversely, resulting to a destabilising effect on cellular membrane of RBCs, decreasing its fluidity and increasing the rate of RBC haemolysis. This appears to be the final effect of ROS-generation and lipid peroxidation in the RBC membrane [26].

The significant increase in WBC in group 2 rats, in comparison with groups 1,3 and 4 may be as a result of the body's immune response to lead toxicity. The significant decrease in the number of neutrophils of rats in groups 2 and 4, in comparison with groups 1 and 3 may be due to defect in granulopoiesis in the bone marrow, caused by lead toxicity.
The significantly higher number of lymphocytes of rats in groups 2 and 4 , in comparison with groups 1 and 3 may have contributed to the observed higher WBC in groups 2 and 4 .

\section{CONCLUSION}

The results from this study indicate that ginger extract has a marked protective effect on sperm quality (motility and viability) and haematological profile in lead acetate-treated male rats. The results also show that ginger may be more effective, when supplemented in animals diet rather than using it as a therapeutic agent after the occurrence of lead toxicity. The potential clinical significance of the findings of this study is that ginger is effective as a prophylactic agent, but has no curative effect.

\section{DECLARATIONS}

\section{Conflict of interest}

No conflict of interest is associated with this work.

\section{Contribution of authors}

This study was done by us, and we accept every liability pertaining to claims relating to the content of this article. RI Odo and EC Mbegbu designed the study, and supervised the experimentation. RI Odo and LN Anyanwu collected, and analysed 
the data. The manuscript was written by RI Odo and EC Mbegbu, and all authors edited it, and approved it for publication.

\section{Open Access}

This is an Open Access article that uses a funding model which does not charge readers or their institutions for access and distributed under the terms of the Creative Commons Attribution License (http://creativecommons.org/licenses/by/ 4.0) and the Budapest Open Access Initiative (http://www.budapestopenaccessinitiative.org/rea d), which permit unrestricted use, distribution, and reproduction in any medium, provided the original work is properly credited.

\section{REFERENCES}

1. White $L D$, Cory-Slechta $D A$, Gilbert ME, TiffanyCastiglioni E. New and evolving concepts in the neurotoxicology of lead. Toxicol Appl Pharm 2007; 225:1-27.

2. Flora SJ, Pande M, Mehta A. Beneficial effect of combined administration of some naturally occurring antioxidants (vitamins) and thiol-chelators in the treatment of chronic lead intoxication. Chem. Biol. Interact 2003; 145(3): 267-280.

3. Sobin C, Montoya MG, Parisi N, Schaub T, Cervantes M, Armijos RX. Microglial disruption in young mice with early chronic lead exposure. Toxicol Lett 2013; 15:00151-00153

4. Wang Y, Wang SQ. Effects of lead exposure on histological structure and antioxidant capacity in the cerebellum of 30-day-old mice. Neural Regen Res2011; 6(14):1077-1081

5. Biswas NM, Ghosh PK. Protection of adrenal and male gonadal functions by androgen in lead-treated rats. Kathmandu Uni Med J 2006; 14:1218-1221.

6. Hamadouche N, Slimani M, Merad-Boudia B, Zaoui C. Reproductive Toxicity of Lead Acetate in Adult Male Rats. Am J Sci Res 2009; (3):38-50.

7. Ashry KM, El-Sayed YS, Khamiss RM, Ibrahim ME. Oxidative stress and immunotoxic effects of lead. Food Chem Toxicol 2010; 236-241.

8. Needleman H. Lead Poisoning. Annu Rev Med 2004; 55:209-22.

9. Prakash J, Shrin P, Adel R. Chemical composition and antioxidant properties of ginger root. J Med PI Res 2010; 4(24): 2674-2679.

10. Zancan KC, Marques MO, Petenate AJ, Meireles MA. Extraction of ginger (Zingiber officinale Roscoe) oleoresin with $\mathrm{CO} 2$ and co-solvents: a study of the antioxidant action of the extracts. J Supercrit Flu 2002; 24: $57-76$.

11. Maghsoudi S, Gol A, Dabiri S, Javadi A. Preventive effect of ginger (Zingiber officinale) pretreatment on renal ischemia-reperfusion in rats. Eur Surg Res. 2011; 46:45-51.

12. Ward JW, Elsea JR. Animal case and use in drug fate and metabolism. Methods and techniques, Vol 1. New York: 1997; $p$ 372-390.

13. Odo RI, Mbegbu EC, Ekere SO, Amaeze CF. Hypoglycemic profile and ameliorative potential of aqueous garlic extract on sperm characteristics in glibenclamide treated diabetic male rats. Afri J Pharm Pharmacol 2018; 12(25): 356-360.

14. Zemjanis $R$. Collection and Evaluation of Semen. In: Diagnostic and Therapeutic Techniques in Animal Reproduction. The Williams and Wilkins Company, Baltimore: 1977; p 139-180.

15. Wells ME, Awa OA. New technique for assessing acrosomal characteristics of spermatozoa. J Diary Sc 1970; 53: 227

16. Coles EH (1986). Veterinary Pathology, 3rd ed. W. B. Saunders Company, Philadelphia:1886; p 145 - 151.

17. Chowdhury AR. Recent Advances in heavy metals induced effect on male reproductive function. Al Ameen J Med Sc 2009; 2(2):37-42.

18. Auger J, Eustache F, Andersen AG, Irvine DS, Suominen $J$, Toppari J, Vierula $M$, Jouannet $P$. Sperm morphological defects related to environment. Hum Reprod 2001; 16(12):2710-2717.

19. Hsu PC, Guo YL. Antioxidant nutrients and lead toxicity. Toxicol 2002;180: 33- 44

20. Sharma $P K$, Agarwal A. A Role of reactive oxygen species in male infertility. Urol 1996; 48: 835-850.

21. Ahmed RS, Seth V, Banerjee BD. Influence of dietary ginger (Zingiber officinale Rosc) on antioxidant defence system in rat: comparison with ascorbic acid. Indian $\mathrm{J}$ Exp Biol 2000; 38:604-606.

22. Chrubasik S, Pittler MH, Roufogalis BD. Zingiberis rhizome; A comprehensive review on the ginger effect and efficacy profiles. Phytomed 2005; 12:684-701.

23. Prakash J, Shrin P, Adel R. (2010). Chemical composition and antioxidant properties of ginger root. $\mathrm{J}$ Med PI Res 2010; 4(24): 2674-2679.

24. Ibrahim TA, Dada IB, Adejare RA. Comparative phytochemical properties of crude ethanolic extracts and physicochemical characteristics of essential oils of Myristical fragrans (nutmeg) seeds and Zingiber officinale (ginger) roots. Electr J Environ Agric Food Chem2010; 9 (6): 11101116

25. Alsaleh M. The biochemical and clinical consequences of lead poisoning. Lancert 1994; 14(4):415-486.

26. Lawton LJ, Donaldson WE. Effects of lead on haematology. Biol Trace Elem Res 1991; 28:83. 